\title{
Trade Deficits Always Matter
}

James W. Gabberty, Pace University, USA

Robert G. Vambery, Pace University, USA

\begin{abstract}
As America grapples over what to do in order to avoid the perils associated with manifest U.S. economic growth that has been characterized as 'barely enough to forestall another recession,' the nation is mired in economic limbo due to, among other causes, the absence of a clearly stated international trade agenda, limited new trade deals, and a lack of concentration on economic growth.
\end{abstract}

Without fiscal clarity, the ability for the U.S. to withstand the burgeoning recessive pressures may prove futile. Meanwhile, China's economy continues to rise, albeit slowly, no doubt reflecting the persistent U.S. slowdown. Europe, not surprisingly, remains in turmoil as European Union naysayers' predictions of dismantling a system designed to prevent abysmal economic performance through uniting various entitlement-minded societies has not yet been vanquished by the positive effects of raising taxes and capital productivity while lowering pensioners' and social program benefits.

The battle for supremacy in this newly dubbed 'G-Zero' world hence remains unclear as governments decide what policies to effectuate and which to eradicate. In the past, economists have downplayed the corrosive effect that continuous ballooning international trade imbalances would have on economic growth.

Finding a meaningful solution to the overall affects that running a persistent trade deficit with other nations has on a national economy has considerable implications. For those economic historians who have studied the U.S. - Japanese trade deficit, for example, a solution to the question of whether a trade deficit is sustainable remains high on the list of questions for which the answers are not altogether clear. Furthermore, the politicians and their supportive economic advisers provide prescriptive advice to the nation's leaders on how to shape trade policy with China, for example, would be enormously benefited by a better understanding of the trade deficit in historical context (say, with Japan) as they shape future trade relations of the U.S. What policy is best for the U.S. economy? Do trade deficits indeed matter?

Keywords: Trade Policy; International Trade; Trade Deficits

\section{INTRODUCTION}

ince the 2012 presidential election, the Obama Administration has repeatedly claimed that they are trying to increase U.S. exports by deliberately stimulating and rejuvenating America's manufacturing sector.

They are in fact doing this to a small extent, but the total effect is moderate and the recent return of previously offshored manufacturing to the U.S. is tied more to the rise of inexpensive natural gas made possible through 'fracking' than to any specific policy out of Washington. Furthermore, the Administration appears to want to subsidize exportation by purposefully keeping down the exchange value of the U.S. dollar or by preventing the escalation of U.S. currency values.

During the ongoing global financial crisis of 2007-2013, and especially with the problems associated with the euro zone, the euro-to-dollar ratio remained quite constant. This could be interpreted or may imply that the relative desirability of U. S. dollars declined together with the relative desirability of the euro. That is, the euro and the dollar fell together when they fell, neither bolstering the other's value as a hedge against inflationary pressures or foreign exchange risks. 
This paper discusses the following key points:

- $\quad$ The United States continues to downplay the relevance and threat posed by the nation's trade deficit (See Figure 1).

- $\quad$ Current exports are up, but only marginally so.

- $\quad$ The enormous US trade deficit exerts downward pressures on the exchange value of the dollar. The U.S. Treasury Secretary and U.S. Federal Reserve Chairman repeatedly claim that they believe in a strong U.S. dollar but their policies tend to be to the contrary. Their actions are oriented toward increasing the supply of U.S. dollars, thereby contributing to the stagnation or decline in the exchange value of the dollar.

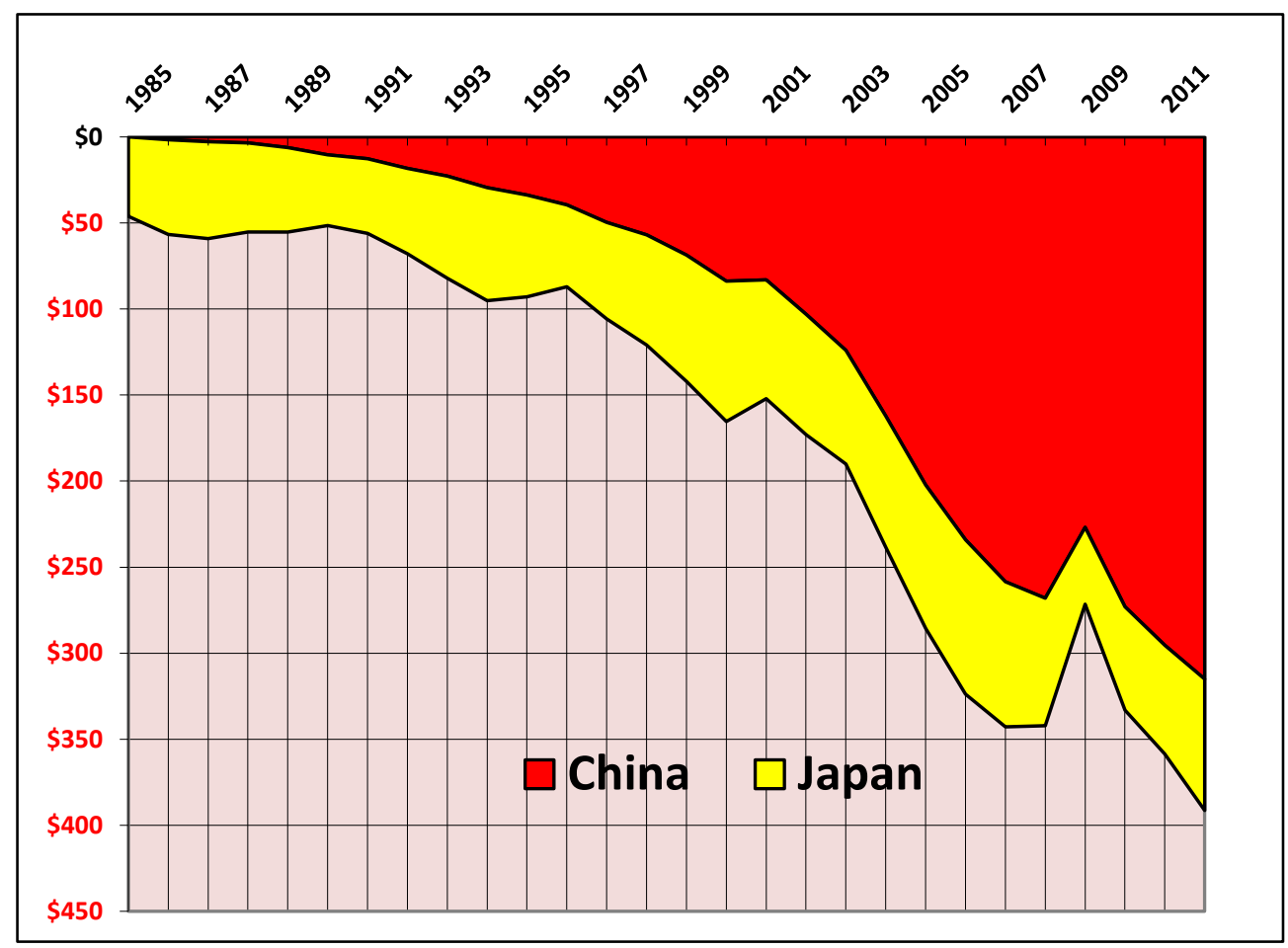

Figure 1: The US Trade with China and Japan is Awash in Deficits (\$ billions)

Source: U.S. Dept. of Commerce Trade data

http://www.census.gov/foreign-trade/balance/c5880.html

It is indisputable that trade deficits have mattered in the past (sometimes causing nations to devalue their currencies), they matter currently (China has enormous leverage over the U.S. from both a political \& economic vantage point), and will in the future (children that are not even born yet are indebted to lender nations). Most assuredly, the aggregate goods and services trade imbalance problem will continue to enervate the relative economic position of the US both domestically and internationally.

Consider the purchasing power of Japan to illustrate why trade matters:

It is astonishing to note that between 1971 and 2011 the exchange value of the Japanese yen has escalated from 360 to 80 yens to the U.S. dollar, as illustrated in Figure 2. With the Japanese yen possessing such enormous purchasing power, virtually anything made in the U.S., whether a product or a service, should be very inexpensive for Japanese customers relative to domestic products and services. Conversely, virtually any product or service produced in Japan should be terribly expensive for U.S. customers. Yet, a substantial Japanese trade surplus against the US was maintained, although at levels somewhat below their previous maximum. 


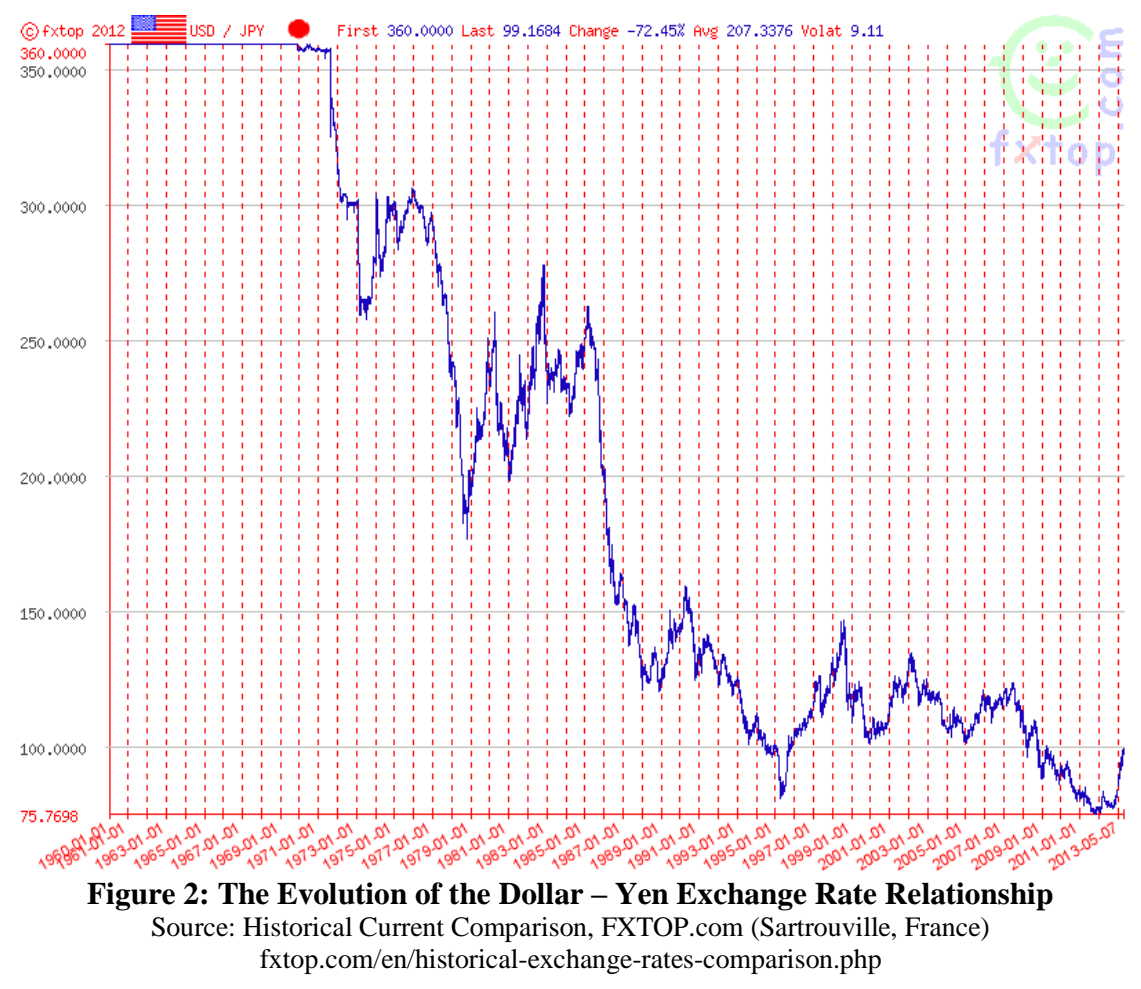

\section{AMERICA'S TRADE DEFICIT IN RETROSPECT}

The gross overvaluation of the Japanese yen over a period of as many as twenty years is a key factor in the two decades-long stagnation of the Japanese economy. The Japanese export sector is greatly hindered, because it requires enormous amounts of foreign currency earnings for Japanese firms to recover the costs they incur during production taking place in Japan.

Since the mid-1990s, we have been arguing that persistent trade imbalances are ruinous to the U.S. economy. Back in 1995, for example, our total trade imbalance was $\$ 92$ billion with Japan and China and for 2012 was $\$ 391$ billion.

Depending on their magnitude and persistence over time, trade deficits are not by themselves intolerably harmful. Even large trade deficits are not necessarily disastrous. Besides their sheer magnitude, the composition of the goods and services imported significantly impact the degree to which deficits are harmful.

For example, the large quantities of oil imported from Saudi Arabia at great expense are essential for U.S. production systems for industrial and consumer goods and for the functioning of military forces. In addition, Saudi Arabia undertakes extensive efforts to buy products, including military hardware, from the United States in order to curtail the magnitude of their trade surplus and its associated adverse financial impacts on the U.S.

These adversities can include downward pressures on the value of the U.S. currency and could have some undesirable impacts on the U.S.' ability to sell treasury instruments abroad. At times Saudi Arabia buys substantial quantities of U.S. government bonds, thereby keeping out of international circulation various amounts of U.S. dollars. Moreover, Saudi Arabia is a key participant in making direct investments in the U.S., taking ownership positions not only in corporate shares, but also direct ownership in certain corporations, especially in the petrochemical industry. These include companies that provide technical services such as prospecting and developing new oil fields. 
During the latter half of 1998, Laura D‘Andrea Tyson, former chairwoman of the President's Council of Economic Advisers and economics professor at Berkeley, wrote a highly-publicized commentary that questioned whether China would replace Japan as the antagonist in America's trade deficit woes. She stated "As the U.S. trade deficit with China continues to increase, concerns mount that China will soon replace Japan as America's major trade headache. Such concerns are fed by an image of China as another Japan - a country pursuing a mercantilist development strategy based on closed markets, an undervalued currency, and a structural trade surplus" (Tyson 1998).

Highlighting Japan's closed markets, undervalued currency, and perennial trade surplus, Tyson's monograph calls into question whether China's trade practices will parallel the manic logic of mercantilism so vehemently practiced by Japan. In brief, her essay allays concern that China's trade behavior will mimic that of Japan's, based on four fundamental economic maxims:

i. China's inconsistent annual current account balances.

ii. Unrestricted foreign direct investment into China.

iii. Rapid fiscal and monetary policy responsiveness by Chinese leaders to market shifts.

iv. Favorable import/export policies by Chinese officials.

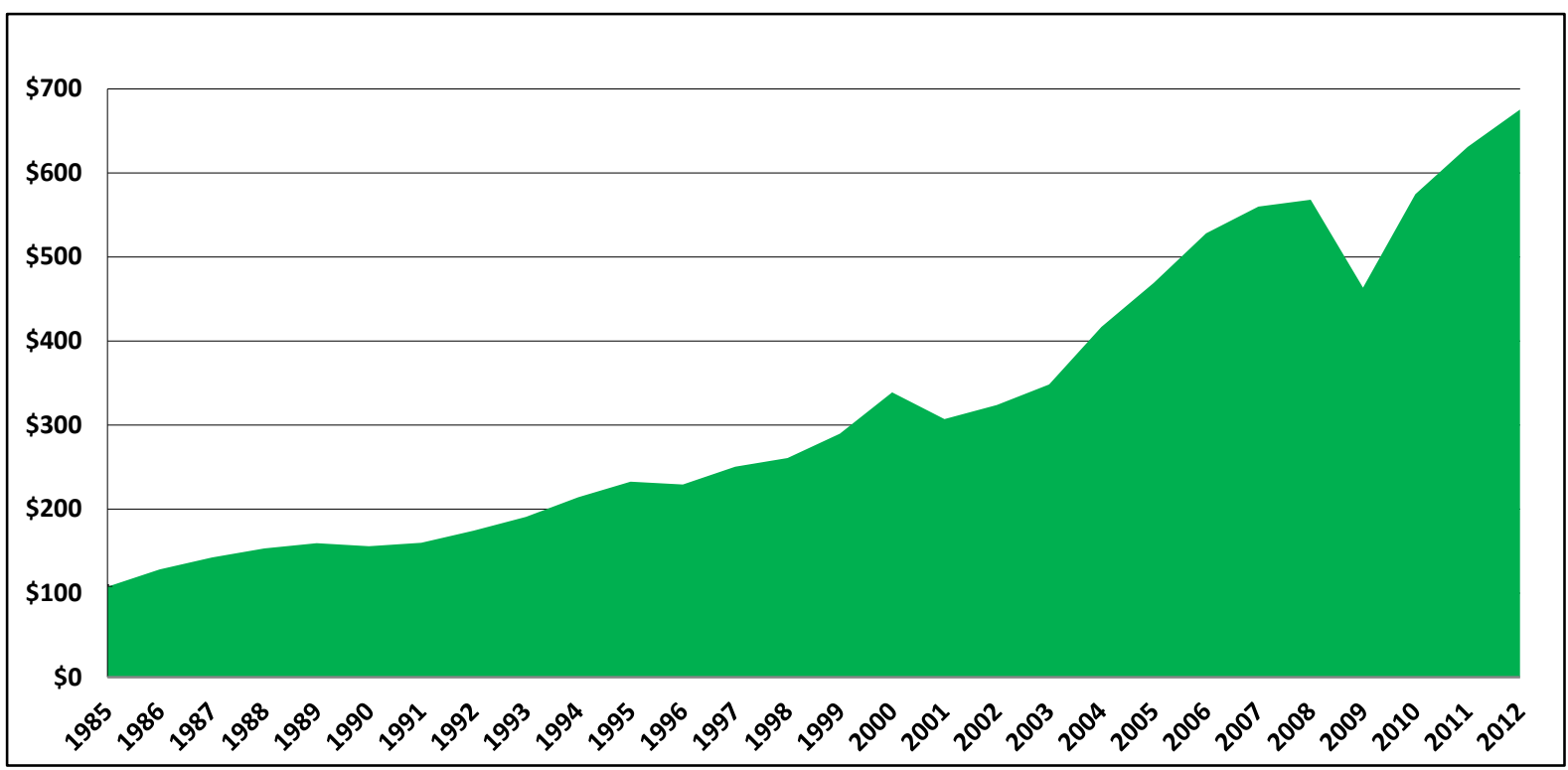

Figure 3: Gains for Select Asian Trading Partners from Trade with the United States (\$ billions)

(China + Japan + South Korea + Taiwan + Singapore)

http://www.census.gov/foreign-trade/balance/c5880.html\#1985

It can be observed that her concerns should have incorporated a more comprehensive view of our relations with key Asian trading partners, all of whom benefitted enormously from their individual dealings with the US, which resulted in transferring vast sums to them from the United States (See Figure 3).

\section{CONCLUSION}

The more than 430 million people living in the U.S. and Japan should join the nearly 1400 million people inhabiting China in celebrating the People's Republic of China (PRC) becoming the world's second largest economy.

Though not evenly developed throughout its regions, China now is a highly industrialized, technologically advanced rich country, with enormous holdings of hard currency, gold, natural resources, knowledge, and capable people. 
For 50 years, the U.S. has been a main supporter of Japan's and for 30 years a main supporter of China's economic development through - 1) extensively opening U.S. markets to Japanese and Chinese exports, 2) allowing and facilitating the transfers of scientific knowledge, technical know-how, patents, production methods and capital goods to Japan and later to the PRC and 3) by providing advanced education to hundreds of thousands of Japanese and (mostly) Chinese citizens.

For decades, Japan has been an advanced, wealthy industrialized country dating back to the 1962 Kennedy Rounds of the General Agreement on Tariffs and Trade, which featured a 'buy Japan' slogan by the U.S. to spur Japanese post-war economic and social development. With all its new and enhanced capabilities, China also now can rapidly acquire, reverse engineer, make use of as well as develop for domestic use and exports a phenomenal variety of products and services including those that incorporate leading edge know how.

China's rapid ascent to the position of second largest economy - on its way to becoming the number one largest economy in the world - should mark a turning point in U.S.-Chinese business relations. There is no longer an economic reason for the U.S. to allow the continuation of the astounding trade imbalances that exploit American markets and impoverish the U.S.

The concessions and practices that give Japan and China, and to a degree to other Asian trading partners such as South Korea and Singapore, the phenomenal advantages in commerce should now be ended. Further and more precisely, the international trade relations between Japan-U.S. and China-U.S. should start to resemble a level playing field, rather than the current hard-to-climb-Mount Fuji or the mountains of the Himalayas.

In its discussions, this paper addressed the adverse impacts of long running, substantial trade deficits on "loser" countries and some of the positive impacts on the "winning" countries. For the U.S., cumulative trade deficits with the world over the past 50 years are in the range of 10 trillion dollars. We may contemplate the benefits foregone even if only a half of that sum would have been invested in the U.S. or spent on economic growthgenerating projects.

\section{AUTHOR INFORMATION}

James W. Gabberty is a professor of information systems at Pace University in New York City. An alumnus of the Massachusetts Institute of Technology and New York University Polytechnic Institute, he has served as an expert witness in telecommunication and information security at the federal and state levels. Gabberty has more than thirty years' experience as a consultant to Wall Street's financial community and authored numerous articles on information and communication technology, the impact of e-commerce, and competitive advantage of nations. He is a certified in IT auditing and risk assessment. E-mail: jgabberty@ pace.edu (Corresponding author)

Robert G. Vambery - PhD, MPhil, MS, BS Columbia University, is a professor of International Business \& Marketing at Pace University. He is a former Managing Editor and Editor at Large of the Journal of International Business Studies. He is co-editor and co-author of the book International Business Knowledge: Managing International Functions in the 1990s. In July 2012 and in July 2013 the Global Business and Technology Association granted him at their fourteenth and fifteenth annual international conferences their prestigious Global Excellence Award. Previously he served on the faculties of the Rutgers University Graduate School of Business and the Columbia University Graduate School of Business. E-mail: Rvambery@ pace.edu

\section{REFERENCES}

1. Bremmer, I. (2012). Every nation for itself: Winners and losers in a g-zero world. New York: Portfolio (Penguin).

2. Gabberty, J. W., \& Vambery, R. (2006, September) Endless surpluses: Japan's successful international trade policy. Journal of American Academy of Business.

3. Gabberty, J. W. (2005). The rising U.S. trade deficit with China and why it won't go away. International Business and Economics Research Journal, 4(1), 11-22. 
4. Tyson, L. D. (1998). Don’t worry, China isn’t following in Japan's footsteps. Business Week, April 20.

5. Vambery, R. G., \& Gabberty, J. W. (1996). Reengineering U.S. international trade policy - the economic competitiveness of the U.S. and Japan in the international marketplace. Journal of the Academy of Business Administration, 2(2), 65-80. 